\title{
Pemasyarakatan Hasil Penelitian Arkeologi: Sebuah Kerangka
}

\section{Sugeng Riyanto}

Keywords: public archaeology, socialization, outreach, communication, information, research

\section{How to Cite:}

Riyanto, S. (2003). Pemasyarakatan Hasil Penelitian Arkeologi: Sebuah Kerangka. Berkala Arkeologi, 23(1), 132-145. https:// doi.org/10.30883/iba.v23i1.868

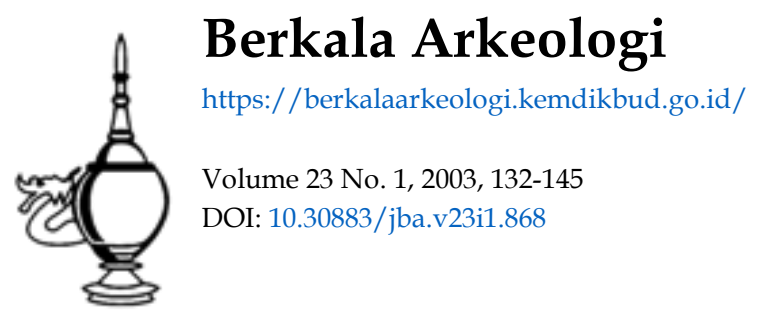

\section{cc) (1)(2)}

This work is licensed under a Creative Commons Attribution-NonCommercial-ShareAlike 4.0 International License. 


\title{
PEMASYARAKATAN HASIL PENELITIAN ARKEOLOGI: SEBUAH KERANGKA
}

\author{
Sugeng Riyanto
}

\begin{abstract}
Carrey dan Quirk (1973):
“...Karena masa depan selalu berada di luar pentas, dan tak pernah benar-benar memasukkan dirinya ke dalam sejarah; masa depan adalah saat yang tak pernah tiba namun senantiasa ditunggu ..."

(Nasution, 1989: 124)
\end{abstract}

\section{B}

\section{INGKAI KOMUNIKASI}

Istilah "pemasyarakatan" sebenarnya sangat dekat dengan "sosialisasi" karena keduanya merupakan proses atau kegiatan memasyarakatkan sesuatu. Dalam Kamus Besar Bahasa Indonesia misalnya, "pemasyarakatan" diartikan sebagai (kata benda) hal atau tindakan memasyarakatkan (memasukkan ke dalam masyarakat, menjadikan sebagai anggota masyarakat) (Moeliono, 1999). Sementara itu dalam ilmu komunikasi "pemasyarakatan" diartikan sebagai penyediaan sumber ilmu pengetahuan yang memungkinkan orang bersikap dan bertindak sebagai anggota masyarakat yang efektif yang menyebabkan ia sadar akan fungsi sosialnya sehingga ia dapat aktif di dalam masyarakat (Effendy, 2003). Tepat ataupun meleset makna kedua pengertian tersebut pada pengertian "pemasyarakatan hasil penelitian arkeologi", menjadi tidak penting ketika kita sepakat bahawa keduanya memiliki kata kunci yang sama yaitu "berkomunikasi dengan khalayak".

Tidak akan ada yang menganggap salah jika kegiatan seperti penerbitan hasil penelitian arkeologi, pameran, penyuluhan, pertemuan ilmiah, atau bentuk publikasi yang lain dikategorikan sebagai "pemasyarakatan" hasil penelitian arkeologi. Pada dasarnya kegiatan-kegiatan tersebut adalah upaya untuk menginformasikan hasil penelitian arkeologi kepada masyarakat. Namun tentu saja tujuannya tidak sekedar memberikan informasi tanpa peduli apakah efeknya sesuai dengan yang diharapkan dan direncanakan. Sementara itu informasi menjadi operasional melalui komunikasi (Nasution, 1989). Oleh karena itu penting artinya untuk memandang dan menempatkan pemasyarakatan hasil penelitian arkeologi di dalam bingkai prinsipprinsip komunikasi.

Ada beberapa hal penting - jika kita sepakat untuk memasyarakatkan (hasil) penelitian arkeologi dalam bingkai komunikasi - yang patut menjadi panduan dalam mengevaluasi dan mengembangkan kegiatan yang oleh sementara orang disebut dan 
diakui sebagai salah satu bentuk akuntabilitas kepada pemerintah dan masyarakat. Butir-butir bingkai komunikasi ini antara lain adalah:

- Sifat dasar komunikasi, minimal harus mengandung kesamaan makna antara dua pihak yang terlibat (Effendy, 2003). Dalam hal ini peran isi, lambang (bahasa), dan media sudah semestinya disesuaikan dalam berkomunikasi.

- Komunikasi diartikan sebagai proses penyampaian pesan oleh komunikator kepada komunikan melalui media yang menimbulkan efek tertentu (Effendy, 2003). Oleh karena itu komunikasi memiliki sedikitnya lima unsur, yaitu:

- Komunikator

- Pesan

- Media

○ Komunikan

○ Efek

- Komunikasi bertujuan untuk (ibid):

- Mengubah sikap komunikan

- Mengubah pendapat

- Mengubah perilaku

- Efek perubahan sosial

- Sedangkan fungsi komunikasi adalah (ibid.):

- Menyampaikan informasi

- Mendidik

- Menghibur

- Mempengaruhi

- Komunikasi eksternal terdiri atas (ibid):

- Komunikasi dari organisasi kepada khalayak: pada umumnya bersifat informatif, yang dilakukan sedemikian rupa sehingga khalayak merasa memiliki keterlibatan, setidak-tidaknya ada hubungan batin. Bentuk komunikasi ini antara lain melalui majalah organisasi, press release, artikel (surat kabar atau majalah), pidato (radio dan televisi), film dokumenter, brosur, leaflet, poster, konferensi pers, dll.

- Komunikasi dari khalayak kepada organisasi: merupakan umpan balik sebagai efek dari kegiatan komunikasi yang dilakukan olah organisasi.

Berdasarkan butir-butir di atas, siklus komunikasi dapat digambarkan sebagai berikut (ibid): 


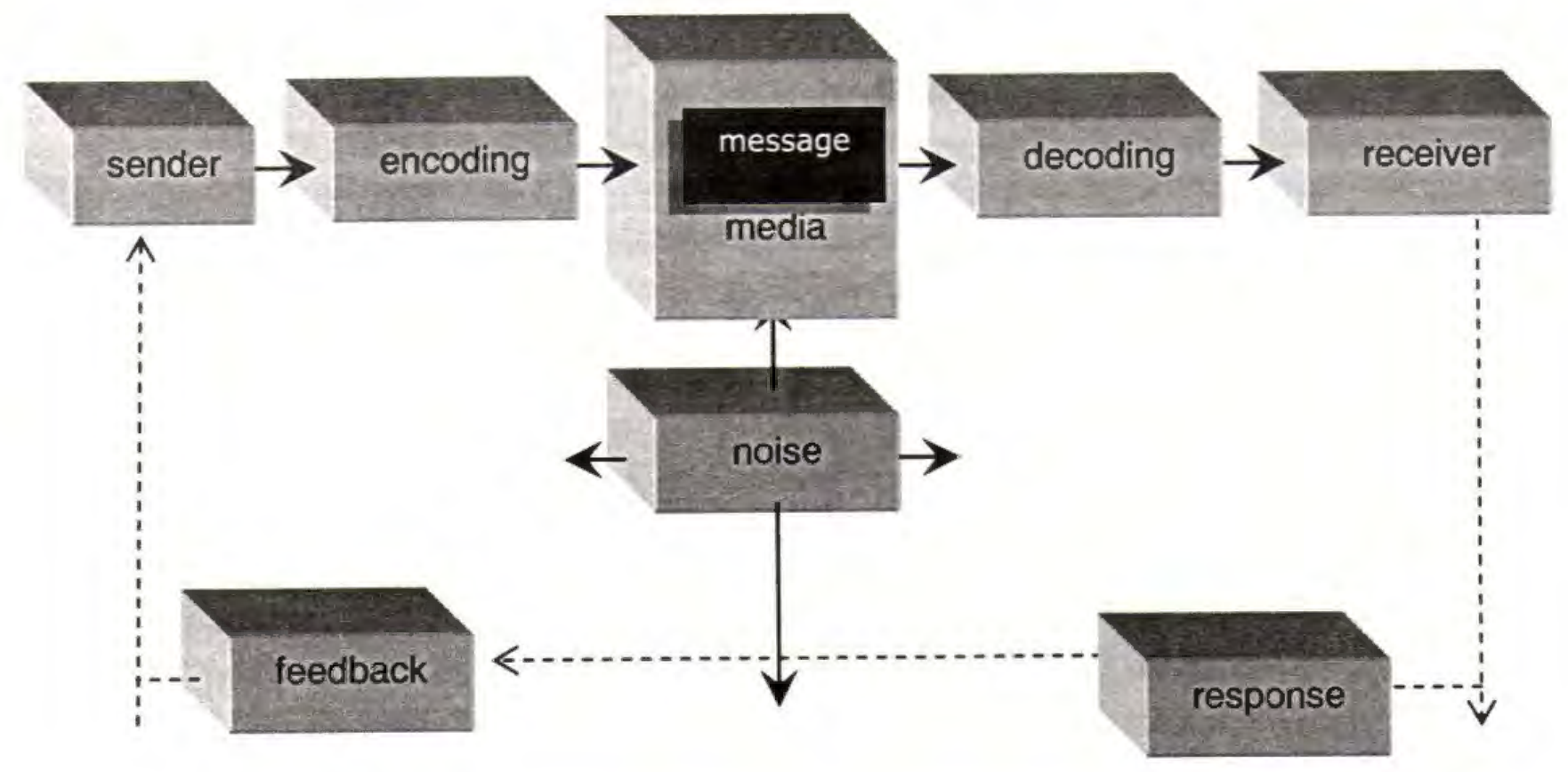

- Sender: komunikator yang menyampaikan pesan kepada seseorang atau sejumlah orang

- Encoding: penyandian, yaitu proses pengalihan pikiran ke dalam bentuk lambang

- Message: pesan yang merupakan seperangkat lambang bermakna yang disampaikan oleh komunikator

- Media: saluran komunikasi tempat berlalunya pesan dari komunikator kepada komunikan

- Decoding: pengawasandian, yaitu proses di mana komunikan menetapkan makna pada lambang yang disampaikan oleh komunikator

- Response: seperangkat reaksi komunikan setelah menerima pesan

- Feedback: umpan balik, tanggapan komunikan yang disampaikan kepada komunikator

- Noise: gangguan yang tidak direncanakan yang terjadi dalam proses komunikasi

Sehubungan dengan pemasyarakatan (hasil) penelitian arkeologi, Puslit Arkeologi dan Balai Arkeologi adalah sender, informasi (hasil) penelitian arkeologi adalah message, dan khalayak sebagai receiver. Sementara itu sebagai medianya adalah penerbitan, pameran, dsb. seperti yang telah dilakukan selama ini. Pertanyaannya, apakah pemasyarakatan (hasil) penelitian arkeologi selama ini sudah efektif? Untuk itulah diperlukan adanya evaluasi yang nantinya dijadikan sebagai salah satu dasar dalam mengembangkan kegiatan pemasyarakatan ini. 


\section{$\mathbf{K}$}

ERANGKA EVALUASI

Pada dasarnya seluruh kegiatan (penelitian) arkeologi yang dilaksanakan oleh tahap pencetusan gagasan, perjuangan ke dalam blue-print, penusu (DUP/DUK), program, mobilisasi sumber daya (dana, tenaga, waktu, dan kepakaran), pelaksanaan, pengolahan hasil (yang pada umumnya makan waktu berkepanjangan) sampai akhirnya tahapan penyajian (melalui/dalam bentuk makalah, penerbitan, dan penyebarluasan informasi) (Nies Anggraeni, 1999). Pernyataan ini sekaligus dapat digunakan sebagai sebuah kesepakatan dan pengakuan bahwa penyebarluasan informasi hasil penelitian arkeologi merupakan bagian yang tidak terpisahkan dari kegiatan penelitian arkeologi. Artinya, berbagai bentuk evaluasi, pengendalian, perencanaan, dan pengembangan penelitian arkeologi secara otomatis di dalamnya termasuk kegiatan pemasyarakatan sebagai bagian integral dari penelitian arkeologi.

Dalam kerangka evaluasi, ada dua hal penting untuk memulai evaluasi kegiatan pemasyarakatan, yaitu produk (dan kegiatan) serta distribusi. Di dalam kedua hal tersebut memuat unsur-unsur yang dapat dievaluasi sebagai dasar untuk perencanaan dan pengembangannya.

Unsur-unsur evaluasi pada produk (dan kegiatan) meliputi:

- Jenis / bentuk: termasuk di dalamnya adalah produk berupa:

- penerbitan berbagai bentuk baik ilmiah, semi populer, maupun populer, - media massa meliputi elektronik (televisi, radio) dan cetak (koran, majalah)

- publikasi digital seperti audio-visual, multi media, CD-interaktif, jaringan (LAN, Website, Intranet)

- pemasyarakatan langsung seperti kegiatan pameran, ceramah, penyuluhan

- internal seperti pertemuan ilmiah dan perpustakaan.

Evaluasi jenis / bentuk produk dan kegiatan terutama diarahkan pada kemungkinan mempertahankan, mengubah, merombak, mengembangkan, mengurangi, atau justru menambah jenis dan bentuk pemasyarakatan yang sudah ada, termasuk di dalamnya kemungkinan untuk memanfaatkan teknologi informasi. Jenis (produk) dan bentuk (kegiatan) ini nantinya akan menjadi inti bagi pemasyarakatan hasil penelitian arkeologi karena memiliki kedudukan dan peran sebagai jembatan (media komunikasi) antara organisasi (puslit dan UPT) dengan khalayak.

- Proses: Evaluasi pada proses hampir sama dengan mengamati "dapur" atau "bengkel" yang paling tidak mencakup tiga fungsi manajemen, yaitu perencanaan, pelaksanaan, dan monitoring Di dalam evaluasi proses "produksi" (khususnya untuk penerbitan dan publikasi digital) dan pelaksanaan kegiatan (pemasyarakatan langsung dan internal) sangat perlu untuk dikemukakan strategi dan kerja sama yang sudah dilakukan. Dalam hal ini sangat penting artinya untuk menginventarisasi berbagai kendala, hambatan, unsur penunjang, dan peluang 
yang ada dalam proses baik perencanaan, pelaksanaan, maupun monitoring (termasuk penerapan strategi dan kerja sama). Semakin besar jumlah inventarisasi tersebut akan semakin baik untuk dijadikan sebagai bahan evalusi.

- Kuantitas: dalam hal ini berkaitan dengan jumlah dan frekuensi. Dari segi kuantitas, evaluasi barangkali bisa dimulai dengan pertanyaan, seperti: penetapan jumlah dan frekuensi pemasyarakatan hasil penelitian arkeologi didasarkan pada faktor (-faktor) apa? Apakah didasarkan pada anggaran, apakah didasarkan pada kebutuhan, apakah didasarkan pada "sesuatu", atau justru sama sekali tidak didasarkan pada apapun? Oleh karena itu, juga sangat penting artinya untuk menginventarisasi berbagai kendala, hambatan, unsur penunjang, dan peluang dalam menetapkan jumlah dan frekuensi. Pertanyaan lain, misalnya, apakah kuantitas yang ada selama ini sudah ideal, dalam arti tidak berlebih dan tidak terlalu sedikit?

Sementara itu unsur-unsur evaluasi pada distribusi mencakup:

- Sasaran: secara umum sasaran kegiatan pemasyarakatan hasil penelitian arkeologi adalah khalayak (society). Akan tetapi kita ketahui bahwa di dalam khalayak terdapat sejumlah unsur, kelompok, lapisan, karakter, tingkat pendidikan, dsb. yang tidak dapat dianggap, dipandang, dan diperhitungkan secara seragam. Barangkali tidak terlalu berlebihan jika khalayak dalam hal ini dipandang sebagai "pasar" bagi informasi hasil penelitian arkeologi. Keberadaan "pasar" terkait secara langsung dengan produk, artinya produk dan kegiatan yang didistribusikan dan dilaksanakan mesti disesuaikan dengan sasaran. Dalam hal ini evaluasi bisa dimulai dari menginventarisasi sasaran-sasaran yang selama ini menjadi "langganan" distribusi kita. Evaluasi juga diarahkan untuk mencari kemungkinan pengembangan sasaran yang lebih luas dan terarah melalui "pemetaan pasar" yang menggambarkan pengelompokkan khalayak, tingkat apresiasi, "demand", kebutuhan, karakter, dsb.

- Proses: evaluasi pada proses pendistribusian antara lain meliputi "bagaimana" dan "oleh siapa". Dengan kata lain apakah pendistribusian dilakukan berdasarkan instrumen yang sudah baku? Dalam evaluasi sangat diperlukan adanya inventarisasi berbagai kendala, hambatan, unsur penunjang, dan peluang yang ada dalam proses distribusi untuk menciptakan atau menentukan instrumen bagi proses pendistribusian yang tepat, efektif, dan efisien. Dua hal penting yang tidak bisa ditinggalkan dalam evaluasi proses adalah strategi yang sudah dilaksanakan dan jaringan kerja sama yang ada.

- Control (pengendalian): evaluasi pada pengendalian distribusi didasarkan pada kerangka manajemen sistem, yang mencakup pengendalian pada pelaksanaan rencana (atau segala sesuatu yang sudah direncanakan). Hal-hal yang berhubungan dengan pengendalian adalah aliran informasi dan umpan balik (feedback) sehingga sebuah sistem dapat mengevaluasi perencanaannya (Lucas Jr., 1987). Pertanyaan untuk evaluasi control antara lain: 
- Perlukah mendapatkan feedback dari khalayak? Berdasarkan bingkai komunikasi, umpan balik merupakan salah satu unsur yang menentukan isi pesan dan medianya. Oleh karena itu umpan balik sudah semestinya menjadi salah satu yang dianggap penting dan diperhitungkan dalam kegiatan pemasyarakatan.

- Sudah adakah instrumen control sebagai kendali distribusi termasuk di dalamnya untuk mengukur efek serta menampung respon dan feed-back?

valuasi merupakan bagian paling penting dalam siklus organisasi, termasuk pada kegiatan pemasyarakatan hasil penelitian arkeologi, sebagai dasar bagi pengembangan setelah diolah bersama dengan feedback dari khalayak. Dalam hal ini sistem informasi arkeologi (SIA) menjadi suatu hal yang tidak bisa ditawar lagi, sehingga pengembangannya di arahkan pada pembentukan SIA. Secara garis besar dan sederhana,

Gambar siklus ini sebagai berikut :
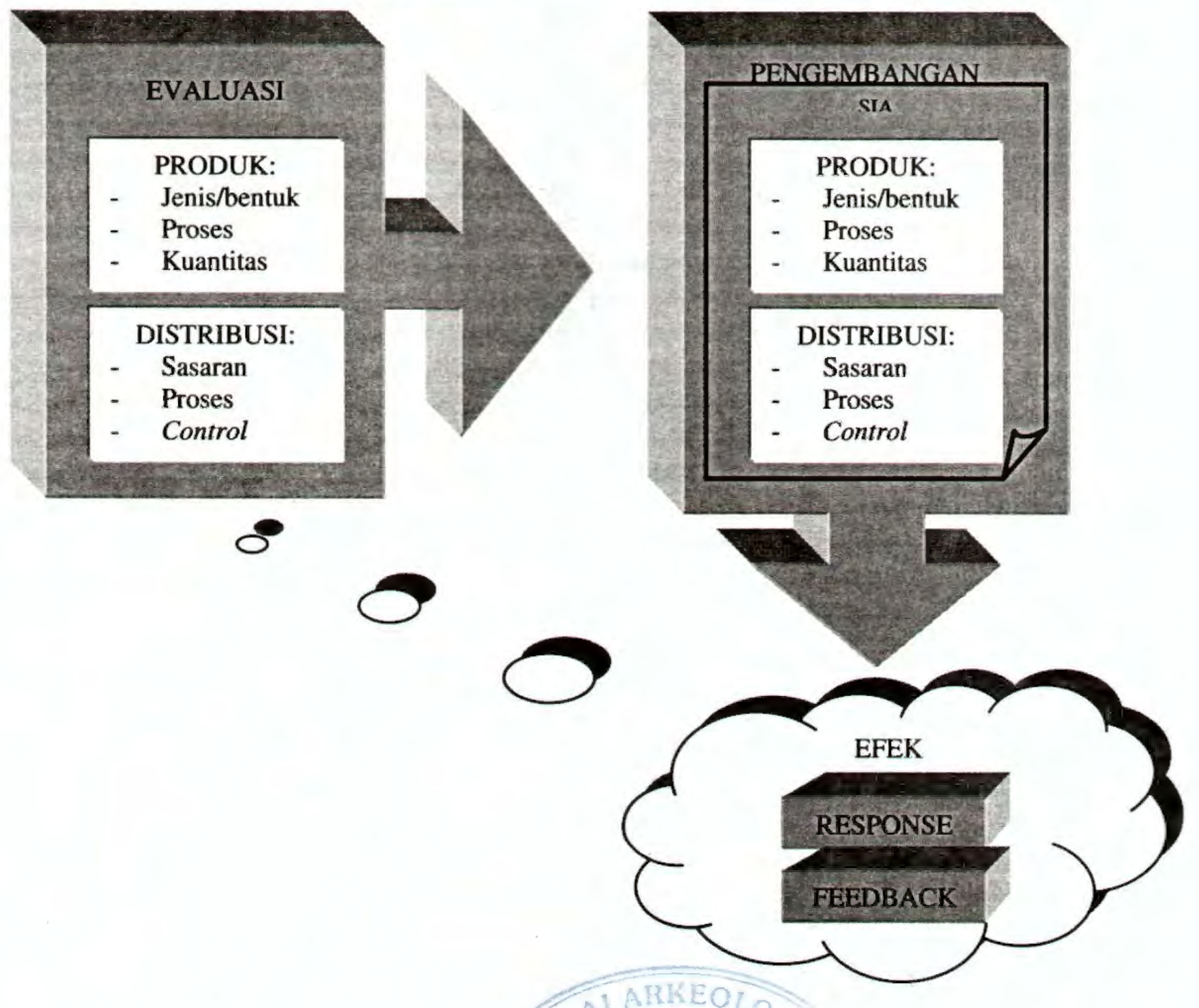


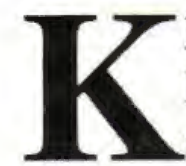

\section{ERANGKA PENGEMBANGAN}

Hasil evaluasi yang meliputi produk (dan kegiatan) serta distribusi selanjutnya dijadikan sebagai salah satu dasar untuk mengembangkan kegiatan pemasyarakatan hasil penelitian arkeologi. Dengan demikian kerangka pengembangkannya juga meliputi kedua hal pokok tadi, dengan penekanan pada kemungkinan membangun "sistem informasi arkeologi" karena di dalamnya tercakup sub-sub sistem atau unsur-unsur yang ada pada produk (dan kegiatan) serta distribusi seperti terlihat pada bagan sederhana di atas.

Sebelumnya barangkali perlu ditinjau kerangka pengembangan produk/kegiatan serta distribusi secara khusus, sebelum membahas tentang SIA. Butir-butir kerangka pengembangan pemasyarakatan hasil penelitia arkeologi yang mencakup produk/kegiatan, antara lain adalah:

- Jenis/bentuk: luasnya jangkauan khalayak sudah sesmestinya diimbangi dengan pengembangan jenis/bentuk pemasyarakatan dan disesuaikan dengan "pangsa pasar" masing-masing. Sebagai contoh:

- Penerbitan: sudah saatnya mengembangkan penerbitan dengan penekanan pada penerbitan yang bersifat semi-populer dan populer dengan pertimbangan "pangsa pasar" yang lebih luas. Pengemasan, gaya penulisan, isi, dan aspek teknis lainnya agar disesuaikan dengan prinsip-prinsip penerbitan semipopuler dan populer. Namun demikian penerbitan ilmiah juga perlu dikembangkan baik kuantitas maupun kualitasnya, termasuk pengemasannya.

- Media massa: Selain mendorong para peneliti untuk proaktif dalam mengisi berbagai kolom di media massa cetak, tidak ada salahnya jika dipikirkan kemungkinan untuk berkerja sama dengan media cetak tertentu guna berlangganan kolom khusus arkeologi secara berkala. Yang perlu dipertimbangkan dalam hal ini antara lain adalah rating; semakin tinggi rating media massa akan semakin efektif informasi yang disebarkan. Tidak jauh berbeda dengan media cetak, juga pada media elektronik (TV/radio) selain mendorong peneliti atau kelompok peneliti untuk proaktif tampil dan mengisi berbagai tayangan atau jam siar baik di TV maupun radio, perlu juga dipikirkan kemungkinan kerja sama dengan media elektronik untuk berlangganan jam tayang / jam siar khusus secara berkala.

- Publikasi digital: isitilah ini didasarkan pada kemasan informasi yang bukan lagi berbentuk hardcopy atau analog tetapi sudah $100 \%$ digital, termasuk di dalamnya teks, foto, gambar, peta, audio, video, dsb. Sementara itu bentuk kemasannya antara lain adalah CD-interaktif, video digital (VDC/DVD), dan jaringan (LAN, web-site, intranet). Pengembangan publikasi jenis ini sangat dekat dengan pemanfaatan IT (teknologi informasi) yang berkembang beriringan dengan teknologi komunikasi dengan begitu pesat sehingga para ahli menyebut gejala ini sebagai revolusi (Nasution, 1989). Sementara itu komponen dasar IT adalah: perangkat manusia (brainware), prosedur (aturan- 
aturan yang berlaku dalam sistem), dan basis data (Fathansyah, 2001). Pada dasarnya, IT merupakan subsistem dari sistem informasi yang berkaitan dengan teknologi infrastruktur. Oleh karena itu pembahasan lebih lanjut mengenai publikasi digital akan terangkum dalam pembahasan tentang SIA.

- Pemasyarakatan langsung: Berbeda dengan bentuk publikasi di atas yang tidak secara langsung kontak dengan khalayak, pameran, penyuluhan dan ceramah secara langsung berhadapan dengan khalayak. Namun demikian, kekurangan bentuk ini adalah jumlah khalayak yang cenderung terbatas, khususnya pada lokasi tertentu. Khusus untuk pameran, sudah saatnya untuk menerapkan strtategi "jemput bola" dan tidak hanya menunggu khalayak. Strategi ini pada prinsipnya berkaitan dengan lokasi; dalam hal ini bukan kita yang menentukan, akan tetapi sudah disesuaikan dengan tempat keramaian berada, misalnya pada keramaian multievent. Substansi pameran disesuaikan dengan jenjang atau skalanya, yang paling tidak meliputi lokal, nasional, dan internasional. Sedangkan untuk ceramah dan penyuluhan, pengembangan khususnya diarahkan pada kuantitas (jumlah dan frekuensi) dan tekniknya, misalnya dengan memanfaatkan multi media. Agar pelaksanaannya dapat berkesinambungan pada frekuensi tertentu, sudah saatnya untuk membentuk institusi khusus (non-formal) yang betanggung jawab pada program (pameran, ceramah, penyuluhan), peralatan dan perlengkapan, pelaksanaan, dst. Eksistensi institusi ini tidak bergantung pada orang (-orang) akan tetapi bergantung pada aturan-aturan pokok, mekanisme, dan program yang mapan; artinya, orang (-orang ) yang berada di dalam institusi bisa siapa saja dan menjadi terikat serta berperan sebagai pelaksana teknis dan manajerial.

- Internal: disebut interal karena pemasyarakatan jenis ini ditujukan untuk kalangan terbatas, khususnya dunia arkeologi. Kegiatan ini memiliki arti penting, khususnya bagi pengembangan akademis penelitian arkeologi. Kerangka pengembangan pertemuan ilmiah diarahkan pada pembentukan institusi, aturan-aturan pokok, prosedur dan mekanisme, termasuk di dalamnya pengaturan kuantitas (jumlah dan frekuensi) serta penjenjangan (lokal, nasional, internasional). Sementara itu kerangka pengembangan perpustakaan diarahkan pada pembentukan perpustakaan digital. Khusus untuk hal ini diperlukan pentahapan yang ketat dengan target pada setiap tahap yang jelas dan mudah dicapai; jumlah tahap tidak terlalu penting, justru rangkaian pentahapan itulah yang lebih penting. Hal ini bisa dimulai dari sebagai contoh - inventarisasi koleksi (termasuk penagihan), penyempurnaan Buku Induk, pembentukan prosedur (aturan, mekanisme, alur kerja, dst.), digitasi (termasuk aplikasi dBase), dsb.

- Proses: meskipun secara formal Puslit Arkeologi memiliki institusi Dokumentasi dan Publikasi, bukan berarti proses dalam produk/kegiatan sudah pasti "beres". "Dapur" atau "bengkel" yang di dalamnya meliputi perencanaan, pelaksanaan, dan monitoring terikat begitu erat dengan unit yang lain, karena penyebaran 
informasi adalah bagian integral dari penelitian arkeologi. Berbagai kendala, hambatan, unsur penunjang, dan peluang yang ada dalam proses baik perencanaan, pelaksanaan, maupun monitoring (termasuk penerapan strategi dan kerja sama) sudah saatnya diformulasikan untuk kemudian diciptakan konsep prosedur (aturan dan mekanisme) yang didukung oleh semua unsur penelitian.

- Kuantitas: jumlah dan frekwensi produk/kegiatan pemasyarakatan sudah saatnya ditetapkan secara sistematis (terencana, sesuai kebutuhan, dan terkendali). Tidak ada salahnya jika kuantitas ditetapkan secara bertahap, dimulai dari yang paling mudah dicapai (minimal), standar, dan berkembang pada tingkat yang ideal.

Kerangka pengembangan yang berkaitan dengan distribusi meliputi:

- Sasaran: Secara garis besar sasaran atau "pasar" bagi pemasyarakatan hasil penelitian arkeologi paling tidak meliputi tiga kalangan, yaitu: akademik, pemerintah, dan umum. Namun, sebagai individu sebenarnya pengelompokan tersebut kurang tepat karena individu "anggota" kelompok akademik, misalnya, dengan mudah bersifat dan bersikap umum, atau sebaliknya, dst. Sementara itu kalangan umum juga dapat mencakup baik kalangan akademik maupun pemerintah. Oleh karena itu diperlukan kerja keras untuk "menggambar peta" sasaran secara lebih logis, lebih detil, dan lebih akurat, termasuk persebarannya, tingkat apresiasi, pendidikan, ketersediaan sarana informasi, kemudahan akses, dst.

- Proses: Sudah saatnya proses distribusi ditempatkan sebagai bagian integral dari pemasyarakatan, dan bukan bagian yang berdiri sendiri. Artinya perencanaan, prosedur (mekanisme dan aturan), dan pelaksanaannya sudah didasarkan pada instrumen baku sehingga kendala dan hambatan dapat diperkecil. Sebagai contoh, ketika sebuah buku dicetak, proses distribusi sudah direncanakan, baik cara maupun sasarannya. Selain itu, konsep untuk menetapkan strategi dan jaringan kerja sama dalam hal distribusi ini sangat diperlukan untuk memperlancar alur penyampaian informasi kepada khalayak. Berbagai peluang juga sudah saatnya untuk dimanfaatkan.

- Control: dua hal penting pada pengendalian distribusi, yaitu 1) untuk memastikan bahwa informasi sampai pada sasaran yang dituju, 2) menampung efek dari khalayak yang telah menerima informasi, termasuk respon dan feedback. Selain itu efek (respon dan feedback) perlu diolah sebagai bahan evaluasi, dan pada gilirannya kembali menjadi salah satu bahan untuk pengembangan kegiatan pemasyarakatan. Cara atau strategi yang dapat ditempuh, misalnya: pada setiap penerbitan dilampirkan formulir khusus untuk komentar, usulan, dsb. Dengan disertai alamat jelas redaksi. Strategi umum yang barangkali perlu dipikirkan untuk mendapatkan feedback adalah dengan mengadakan survei dengan menggunakan kuesioner yang sekaligus ditujukan untuk mendapatkan gambaran tentang apresiasi, kebutuhan, permintaan, minat, dsb. 


\section{$\mathbf{K}$}

ERANGKA SISTEM INFORMASI (ARKEOLOGI)

Secara sempit Sistem Informasi diartikan sebagai sekumpulan prosedur pengambil keputusan dan/atau untuk pengendalian organisasi (Lucas Jr., 1987). Sedangkan secara luas Sistem Informasi merupakan proses pengumpulan, pemrosesan, penyimpanan, analisis, dan penyebaran informasi utk kepentingan tertentu yang terdiri atas input (data \& instruksi) dan output (Sugeng Riyanto, tt).

Selain itu, SI digambarkan sebagai:

- Pengumpulan, pemrosesan, penyimpanan, analisis, dan penyebaran informasi utk kepentingan tertentu

- Terdiri atas input (data $\&$ instruksi) dan output

- Memproses input untuk menghasilkan output yg dikirim ke user atau sistem yang lain

- Beroperasi dalam suatu lingkungan tertentu

Sesuai dengan perkembangan teknologi, sudah saatnya SI dibangun dengan memanfaatkan teknologi komputer untuk melaksanakan berbagai prosesnya. Untuk itu, diperlukan komponen dasar berupa:

- hardware: prosesor, monitor, keyboard, scanner, printer, dsb.

- Software: kumpulan program, aplikasi, modul

- dBase: kumpulan file, tabel, record, entitas, dsb

- Network: jaringan antar sistem komputer baik lokal maupun publik

- Procedures: aturan \& mekanisme pengoperasian sistem

- SDM: orang-orang yang menjalankan \& bekerja dengan sistem

Penggunaan Teknologi Informasi (IT) pada sistem informasi mempunyai manfaat, antara lain:

- Eliminating: menghindari proses-proses yang tidak perlu

- Simplifying: penyederhanaan berbagai proses yg diperlukan

- Integrating: penggabungan proses-proses ke dalam sebuah alur proses

- Automating: perubahan proses manual menjadi otomatis

Dalam SI terdapat pentahapan pelaksanaan yang tercermin pada out-putnya, yaitu:

- Publishing: publikasi, sekedar informasi, user pasif

- Interactivity: layanan interaktif, informasi disampaikan secara dua arah atau informasi yang membutuhkan campur tangan user untuk diakses (misalnya: CDinteraktif dan website)

- Completing Transactions: melayani user untuk transaksi secara elektronik

- Delivery: layanan sampai pada tingkat pengantaran produk ke user atau pemesan 
Selain hal-hal yang sifatnya teknis dan strategis, ada beberapa hal lagi yang perlu diperhatikan dalam membangun SI, yaitu:

- Penghilangan ego sektoral: tiap-tiap subsistem harus berfikir dan bersikap sebagai bagian dari sistem yang lebih besar, aturan dan mekanisme hanya ada pada tingkat sistem, bukan pada subsistem

- Content yang tepat:

- Core function: pendukung fungsi utama; dalam hal ini adalah penelitian arkeologi

- Internal management function: pendukung pelaksanaan manajemen internal; misalnya kepegawaian, keuangan, perencanaan, dsb.

- Kemudahan mengakses: user (internal maupun eksternal) diberikan keleluasaan mengakes data (yang diijinkan), tidak ada gunanya mempersulit akses.

- Sekuriti dan privasi: aspek keamanan dan privasi menjadi hal paling penting ketika SI berjalan; teknologi menyediakan berbagai cara pengamanan dari berbagai gangguan, untuk itu tidak ada alasan untuk terus-menerus merasa khawatir

- Kemitraan: jalinan kerja sama adalah salah satu aspek penunjang kelancaran perjalanan SI

- Memilih TI yang tepat: pemanfaatan TI disesuaikan dengan kebutuhan; perencanaan dalam hal ini menjadi sangat penting karena tawaran TI begitu melimpah di pasaran

- Berkesinambungan dan perawatan: menjalankan dan merawat biasanya lebih sulit dibandingkan membangun, prosedur dan mekanisme khusus untuk hal ini perlu dipikirkan sebagai pedoman operasional dan perawatan.

Berdasarkan uraian di atas, maka sudah saatnya Puslit Arkeologi dan Balar membangun Sistem Informasi Arkeologi. Berikut ini digambarkan mengenai konsep dasar untuk membangun SIA, sesuai dengan karakter lembaga penelitian, yaitu: 


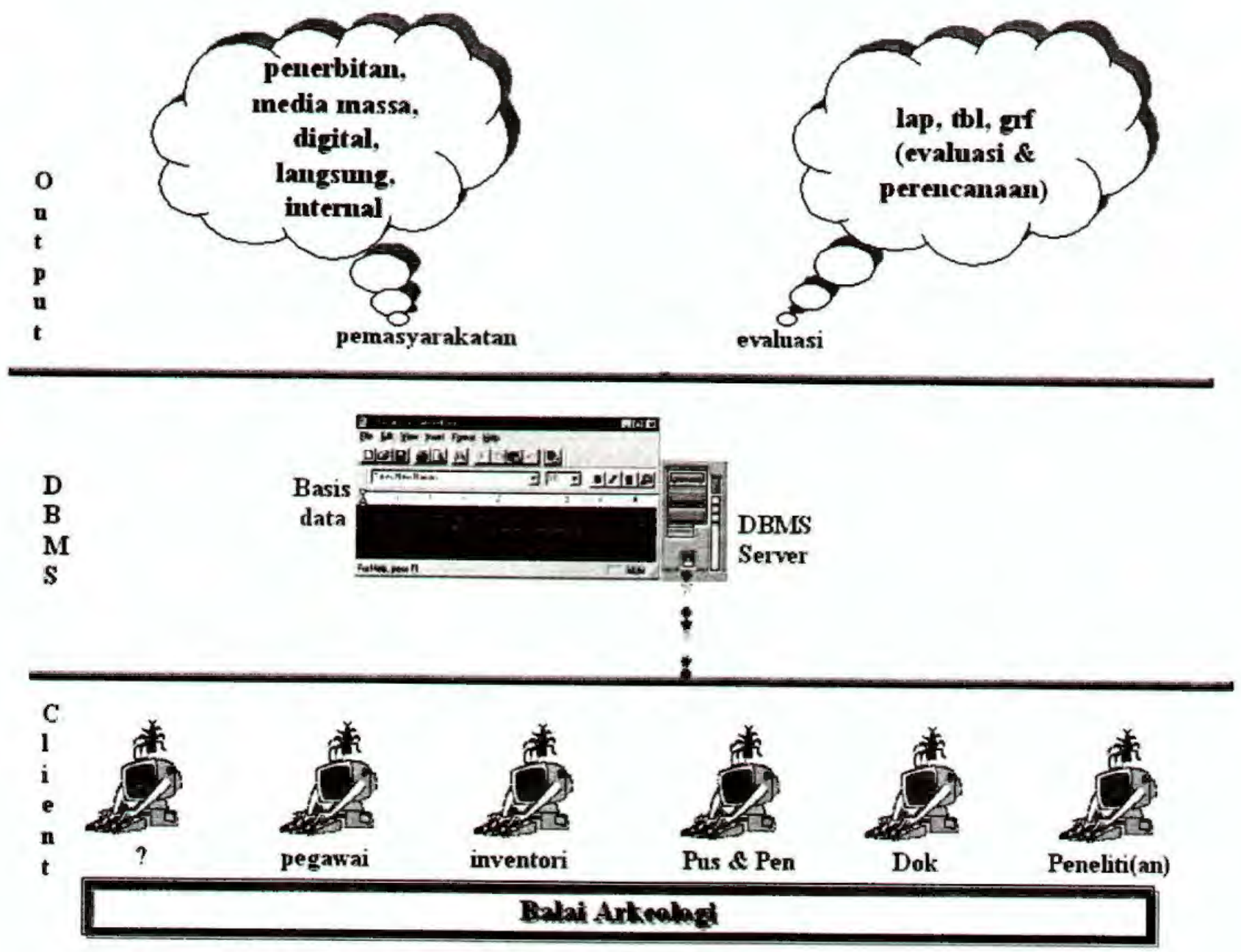

Konsep ini merupakan gambaran umum tentang tiga bagian utama dalam SI, yaitu (1) client yang merupakan unit-unit pemasok (dan pengolah) data sesuai dengan karakter data dan modul yang digunakan, (2) DBMS (Data Base Management System) yang merupakan Basis Data, sehingga komputer yang diperlukan sebaiknya yang berkapasitas sebagai server, dan (3) Out-put, yaitu keluaran yang dapat "dinikmati" dalam berbagai keperluan, baik untuk bahan pemasyarakatan maupun bahan evaluasi manajerial.

Selain itu, secara teknis dalam buku Metode Penelitian Arkeologi telah diuraikan mengenai "komputerisasi dan informasi" (251-261) yang antara lain memuat tentang aspek data, perangkat lunak, perangkat keras, prosedur dan dokumentasi, pelaku sistem informasi, dan pelayanan informasi. Dengan demikian perhatian akan pentingnya sistem informasi sebenarnya sudah lama dipahami, bahkan tercantum secara konseptual dalam buku yang konon menjadi pegangan bagi penelitian arkeologi. Bahkan, pada tahun 1994 hal ini pernah dilontarkan oleh Nurhadi Rangkuti dan Novida Abbas dalam EHPA di Palembang (Rangkuti dan Novida 
Abbas, 1994). Penggabungan antara konsep dasar SIA dengan uraian konseptual tersebut sebenarnya dapat dijadikan sebagai landasan untuk merealisasikan SIA, yang pada pertengahan tahun 1990an sebenarnya sempat berjalan.

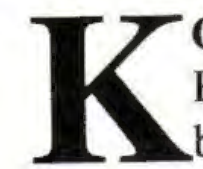

\section{ONSEKUENSI}

Pemasyarakatan hasil penelitian arkeologi memang tidak bisa dilepaskan dari disebut bingkai komunikasi. Komunikasi dan informasi selalu berjalan (lebih tepat dengan istilah SI dan TI.

Masa depan memang selalu berada di depan kita, bahkan ketika kita merasa telah memasukinya. Lahirnya SI antara lain didasarkan pada pentingnya informasi bagi kehidupan dan didukung oleh pesatnya teknologi komunikasi dan akhirnya teknologi informasi (IT) yang antara lain menciptakan kelompok masyarakat baru, yaitu information based society. Informasi bahkan dianggap sebagai salah satu dari tiga sumber daya dasar (basic resources) di samping material dan enerji. Saat ini informasi diakui sebagai suatu komoditi yang antara lain dapat dijual, diberikan, dikopi, diciptakan, disalahartikan, didistorsikan, dan bahkan dicuri (Nasution, 1989). Lebih lanjut disebutkan bahwa pasar informasi global saat ini sudah berlangsung dan yang menjadi etalasenya adalah terminal-terminal komputer yang ada di rumah masingmasing anggota masyarakat (Ibid).

Pelaksanaan evaluasi sebagai dasar pengembangan suatu organisasi selalu menuntut konsekuensi, khususnya tindak lanjut dan pelaksanaan segala sesuatu yang telah diputuskan dan disepakati.Konsekuen artinya sesuai apa yang telah dikatakan atau diperbuat; berwatak teguh, tidak menyimpang dari apa yang telah diputuskan (Moeliono, 1999). Dengan demikian ada dua pilihan bagi kita di masa datang, yaitu: berwatak teguh atau angin-anginan! Namun demikian bukan berarti pelaksanaannya harus buru-buru, tetapi harus sistematis (terencana dan terkendali) dengan menerapkan strategi pentahapan, mulai dari tahap minimal, standar, dan ideal yang berlaku bagi seluruh produk atau kegiatan pemasyarakatan hasil penelitian arkeologi. 


\section{KEPUSTAKAAN}

Effendi, Onong Uchjana. 2003. Ilmu Komunikasi, Teori dan Praktek. (cetakan XVII). Bandung: Penerbit PT Remaja Rosdakarya.

Fathansyah. 2001.Basis Data. (cetakan III). Bandung: Penerbit Informatika.

Lucas Jr., Henry. 1987. Analisis, Desain, dan Implementasi Sistem Informasi. Jakarta: Penerbit Erlangga

Moeliono, Anton M. (ed.). 1999. Kamus Besar Bahasa Indonesia. (cetakan X). Jakarta: Balai Pustaka.

Nasution, Zulkarimein. 1989. Teknologi Komunikasi Dalam Perspektif Latar Belakang dan Perkembangannya. Jakarta: Lembaga Penerbit Fakultas Ekonomi Universitas Indonesia.

Nies Anggraeni. 1999. "Penerbitan Puslit Arkenas, Balar-balar, dan Prosepk Pengembangannya." Makalah disampaikan dalam EHPA Lembang 1999. Tidak terbit.

Rangkuti, Nurhadi \& Novida Abbas. 1994. "Pangkalan Data Arkeologi dan Pembentukan Sistem Informasi Arkeologi". Makalah disampaikan dalam EHPA Palembang, 1994. Tidak terbit.

Sugeng Riyanto. t.t. "Sistem Informasi Arkeologi". Tidak terbit. 